\title{
Effects and Economic Sustainability of Biochar Application on Corn Production in a Mediterranean Climate
}

\author{
Juan Luis Aguirre 1,2,*(D), María Teresa Martín ${ }^{1,2}$, Sergio González ${ }^{1,2}$ and Manuel Peinado ${ }^{2,3}$ \\ 1 Cátedra de Medio Ambiente, Department of Life Sciences, University of Alcalá, 28871 Madrid, Spain; \\ maite.martin@edu.uah.es (M.T.M.); sergio.gonzalezegido@uah.es (S.G.) \\ 2 Environment and Bioproducts Group, Department of Life Sciences, University of Alcalá, 28871 Madrid, Spain; \\ manuel.peinado@uah.es \\ 3 Campus Universitario, Royal Botanical Garden of the University of Alcalá, 28801 Madrid, Spain \\ * Correspondence: juanl.aguirre@uah.es; Tel.: +34-918-854-924
}

Citation: Aguirre, J.L.; Martín, M.T.; González, S.; Peinado, M. Effects and Economic Sustainability of Biochar Application on Corn Production in a Mediterranean Climate. Molecules 2021, 26, 3313. https://doi.org/ 10.3390/molecules 26113313

Academic Editor: M. Gilles Mailhot

Received: 11 May 2021

Accepted: 28 May 2021

Published: 31 May 2021

Publisher's Note: MDPI stays neutral with regard to jurisdictional claims in published maps and institutional affiliations.

Copyright: (c) 2021 by the authors. Licensee MDPI, Basel, Switzerland. This article is an open access article distributed under the terms and conditions of the Creative Commons Attribution (CC BY) license (https:/ / creativecommons.org/licenses/by/ $4.0 /)$.
Abstract: The effects of two types of biochar on corn production in the Mediterranean climate during the growing season were analyzed. The two types of biochar were obtained from pyrolysis of Pinus pinaster. B1 was fully pyrolyzed with $55.90 \%$ organic carbon, and B2 was medium pyrolyzed with $23.50 \%$ organic carbon. B1 and B2 were supplemented in the soil of 20 plots $\left(1 \mathrm{~m}^{2}\right)$ at a dose of $4 \mathrm{~kg} / \mathrm{m}^{2}$. C1 and C2 (10 plots each) served as control plots. The plots were automatically irrigated and fertilizer was not applied. The B1-supplemented plots exhibited a significant $84.58 \%$ increase in dry corn production per square meter and a $93.16 \%$ increase in corn wet weight $(p<<0.001)$. Corn production was no different between B2-supplemented, C1, and C2 plots $(p>0.01)$. The weight of cobs from B1-supplemented plots was $62.3 \%$, which was significantly higher than that of cobs from $\mathrm{C} 1$ and $\mathrm{C} 2$ plots $(p<0.01)$. The grain weight increased significantly by $23 \%$ in B1-supplemented plots $(p<0.01)$ and there were no differences between B2-supplemented, $\mathrm{C} 1$, and C2 plots. At the end of the treatment, the soil of the B1-supplemented plots exhibited increased levels of sulfate, nitrate, magnesium, conductivity, and saturation percentage. Based on these results, the economic sustainability of this application in agriculture was studied at a standard price of $€ 190$ per ton of biochar. Amortization of this investment can be achieved in 5.52 years according to this cost. Considering the fertilizer cost savings of $50 \%$ and the water cost savings of $25 \%$, the amortization can be achieved in 4.15 years. If the price of biochar could be reduced through the $\mathrm{CO}_{2}$ emission market at $€ 30$ per ton of non-emitted $\mathrm{CO}_{2}$, the amortization can be achieved in 2.80 years. Biochar markedly improves corn production in the Mediterranean climate. However, the amortization time must be further reduced, and enhanced production must be guaranteed over the years with long term field trials so that the product is marketable or other high value-added crops must be identified.

Keywords: biochar; corn; rentability; fast pyrolysis; soil analysis; economic analysis; pyrolysis

\section{Introduction}

Pyrolysis, a thermochemical degradation process performed in the absence of oxygen, is currently widely considered a viable option for waste treatment and generation of bioproducts [1]. Most forest residues generated in the field, as well as agricultural residues, are burned on-site as they do not have further applications. This results in the emission of greenhouse gases (GHGs) into the atmosphere and represents a major waste of raw material. One strategy for the management of these residues involves subjecting them to fast pyrolysis, which results in the production of the following four types of products: an aqueous fraction called wood vinegar; a heavy organic fraction called bio-bitumen; a light organic fraction known as bio-oil; a solid fraction called biochar. Additionally, fast pyrolysis results in the production of syngas, which mainly comprises of $\mathrm{CH}_{4}, \mathrm{CO}, \mathrm{H}_{2}$, and $\mathrm{CO}_{2}$ that can feed the biomass heating process [2]. 
Pyrolysis of lignocellulosic residues can be a viable strategy if the resulting products are economically profitable. In particular, the economic benefits of bioproducts obtained through fast pyrolysis (wood vinegar, bio-oil, biochar, and bio-bitumen) should cover the cost of the pyrolysis treatment of these residues.

Wood vinegar has several applications, including herbicidal applications [3,4]. Several studies have demonstrated that wood vinegar can be used as a biostimulant and fertilizer [5-7] and that it enhances the beneficial effects of biochar [8]. Additionally, bio-oil has potential applications as a fuel [9], although the presence of oxygenated compounds can hinder its application. Bio-bitumen has been used as an additive to bitumen from fossil fuels, which reduces its carbon footprint and enhances its properties [10].

Biochar, which comprises of a porous carbonaceous structure with different functional groups, is an extensively researched product with numerous properties [11]. Biochar allows carbon fixation for at least several decades as it can function as a permanent carbon sink and hence can be used to tackle climate change. The emission of thousands of tons of $\mathrm{CO}_{2}$ into the atmosphere can be reduced if the emitted carbon from fires can be transformed into biochar [12]. Moreover, biochar exhibits adsorbent properties, which can improve soil properties [13-15] and promote water retention [16,17]. The supplementation of soil with biochar is reported to increase the availability of basic plant nutrients [18].

Various studies have focused on the effect of biochar supplementation on soil fertility and the productivity of crops, such as corn [19-22], grapevine [23], wheat [24], rice [25,26], barley [27], cotton [28], and potato [29]. Most studies have demonstrated the efficacy of biochar supplementation on crop productivity, while some studies have reported limited or no efficacy of biochar addition in temperate regions where soil fertility is sufficiently high $[30,31]$. In a review on the barriers to the start-up of biochar application in agriculture, Guo et al. 2016 refers to the gap between research and application, immaturity of economical production technologies, lack of application-specific quality standards and management programs [11].

This study aimed to determine the effect of biochar supplementation on corn production in a Mediterranean region in a single growing season. Two types of biochar from Pinus pinaster were tested. Biochar is produced in an industrial reactor of NEOLIQUID technology with internal agitation and external heating. The reactor consists of a screw type reactor with a diameter of $250 \mathrm{~mm}$ and $6 \mathrm{~m}$ length. Biochar B1 comes from a complete pyrolysis process with a residence time of $30 \mathrm{~min}$. However, biochar B2 is produced at a residence time of $15 \mathrm{~min}$.

Additionally, the period for which enhanced productivity should persist for the product to be profitable for a farmer is discussed. Corn was selected in this study as it is one of the most productive and cultivated plants worldwide and improvements in corn production can promote the use of biochar. Most studies examining the effect of biochar on corn plantations were performed in tropical or template climates with limited studies performed in Mediterranean climates where the climatic limitation of rainfall makes it a very irrigated crop. Corn is also one of the most profitable crops in this type of irrigated soil, hence minimal improvements in corn production can benefit the farmers.

\section{Results}

\subsection{Biochar Composition}

Biochar 1 (B1) and biochar 2 (B2) exhibited markedly different compositions. B1 exhibited higher significant levels of organic carbon, organic matter, total humic extract, carbon/nitrogen $(\mathrm{C} / \mathrm{N})$ ratio, and fulvic acid but decreased levels of humic acid and moisture (Table 1). The other variables were not different between the two biochar samples. These findings along with the morphological characteristics of the two types of biochar suggest that B1 was completely pyrolyzed, while B2 underwent partial pyrolysis (nonpyrolyzed wood chips were appreciated). 
Table 1. Basic properties of the two types of biochar used in the experiments. B1: Biochar type 1, B2: Biochar type 2.

\begin{tabular}{ccc}
\hline & B1 & B2 \\
\hline Dry matter & $98.70 \%$ & $81.70 \%$ \\
Moisture & $1.33 \%$ & $18.30 \%$ \\
pH & 8.6 & 7.9 \\
Electrical conductivity $\left(25^{\circ} \mathrm{C}\right)$ & $0.508 \mathrm{dS} / \mathrm{m}$ & $7.54 \mathrm{dS} / \mathrm{m}$ \\
Organic matter $\left(550^{\circ} \mathrm{C}\right)$ & $97.7 \%$ & $49.5 \%$ \\
Organic carbon & $55.90 \%$ & $23.50 \%$ \\
C $/$ N ratio & 233.99 & 33.05 \\
Humic acid & $0.9 \%$ & $4.9 \%$ \\
Total humic extract & $20.3 \%$ & $8.3 \%$ \\
Fulvic acid & $19.40 \%$ & $3.40 \%$ \\
\hline
\end{tabular}

\subsection{Soil Analysis}

The analysis of soil properties indicated that soil fertility was high at the time of planting. All soils were deep soils, fertile, and derived from an alluvial terrace with the following characteristics: organic matter content, $>3 \%$ in most cases; well structured; balanced proportions of sand, silt, and clay; $\mathrm{pH}, 7.6-7.8$. The properties of the soils were not significantly different before planting (Table 2).

Table 2. Number of macronutrients and soil characteristics in soil before and after planting. Control: plots without biochar; B1: plots supplemented with biochar B1; B2: plots supplemented with biochar B2.

\begin{tabular}{|c|c|c|c|c|}
\hline & $\begin{array}{c}\text { Before } \\
\text { Planting } \\
(n=8)\end{array}$ & Control $(\mathrm{n}=4)$ & B1 $(n=2)$ & B2 $(n=2)$ \\
\hline $\mathrm{pH}$ & $7.8 \pm 0.06$ & $7.9 \pm 0.04$ & $8.01 \pm 0.0$ & $7.85 \pm 0.0$ \\
\hline Conductivity $(\mu \mathrm{s} / \mathrm{cm})$ & $264 \pm 49^{*}$ & $293 \pm 28 *$ & $522 \pm 12 *$ & $346 \pm 14^{*}$ \\
\hline Total N $(\%)$ & $0.17 \pm 0.05$ & $0.15 \pm 0.02$ & $0.15 \pm 0.01$ & $0.21 \pm 0.06$ \\
\hline $\mathrm{K}$ assimilable $(\mathrm{mg} / \mathrm{kg})$ & $397 \pm 246$ & $291 \pm 82$ & $453 \pm 22$ & $444 \pm 99$ \\
\hline $\mathrm{P}$ assimilable $(\mathrm{mg} / \mathrm{kg})$ & $50.8 \pm 31.8$ & $30.54 \pm 6.98$ & $38.13 \pm 11.7$ & $37.47 \pm 25.5$ \\
\hline Organic matter $(\%)$ & $3.5 \pm 1.01$ & $3.25 \pm 0.23$ & $4.32 \pm 0.68$ & $5.46 \pm 1.39$ \\
\hline $\mathrm{C} / \mathrm{N}$ & $12.35 \pm 1.1^{*}$ & $12.4 \pm 0.88^{*}$ & $16.68 \pm 1.08$ * & $15.10 \pm 0.22$ * \\
\hline Sulfate (mg/L) & $8.13 \pm 3.4 *$ & $38.25 \pm 6.7 *$ & $142.5 \pm 6.36^{*}$ & $53 \pm 5.8^{*}$ \\
\hline Magnesium (mg/L) & $6.43 \pm 2.4^{*}$ & $9.5 \pm 1.9$ & $14.5 \pm 0.7 *$ & $10.5 \pm 0.7$ \\
\hline Saturation percentage $(\%)$ & $29.1 \pm 1.3$ * & $29.9 \pm 0.5 *$ & $33.64 \pm 1.9 *$ & $33.4 \pm 1.4 *$ \\
\hline Phosphate $(\mathrm{mg} / \mathrm{L})$ & $5.55 \pm 2.76$ & $2.7 \pm 0.4$ & $2.5 \pm 0$ & $3.75 \pm 1.7$ \\
\hline Nitrate $(\mathrm{mg} / \mathrm{L})$ & $28 \pm 2.83 *$ & $9 \pm 2.83$ & $23 \pm 5.6^{*}$ & $4.5 \pm 0.71$ \\
\hline
\end{tabular}

* Significant differences analyzed using analysis of variance, followed by Fisher's test $(p<0.01)$.

No differences were observed in most of the fertility-related variables, such as total nitrogen, potassium, and assimilable phosphorus analyzed after harvesting. The conductivity and carbon to nitrogen $(\mathrm{C} / \mathrm{N})$ ratio of the soil increased after harvesting. The levels of sulfate, magnesium, and saturation percentage were significantly higher in the soils supplemented with biochar. Soils supplemented with B1 retained higher contents of nitrates than the other soils after harvesting.

\subsection{Harvest Data}

\subsubsection{Cob Morphological Data}

The cob insertion height (Fisher's least significant difference (LSD) test; $p>0.05$ in all cases) was not different between different treatment groups. The cob length in the plots with biochar (B1 and B2) was higher than that in the control plots (C1 and C2) (Fisher LSD; $p<0.01$ ). Additionally, the length of cobs was significantly different between $\mathrm{C} 1$ and $\mathrm{C} 2$ plots (Fisher LSD; $p<0.05$ ) but not between the B1-supplemented and B2-supplemented 
plots (Table 3). The perimeter of cobs in the B1-supplemented plots was significantly higher than that in the B2-supplemented, $\mathrm{C} 1$, and C2 plots (Fisher LSD $p<0.01$ ). The cob diameter was significantly different between B1-supplemented and other plots (Fisher LSD; $p<0.01$ ), and between B2-supplemented and C2-supplemented plots (Fisher LSD; $p<0.05$ ). The percentage of cobs with few grains (assumed to be due to the lack of pollination or incomplete pollination) was not different between treatment groups ( $\mathrm{C} 1 \mathrm{plots}, 25.75 \%$; C2 plots, 21.01\%; B1-supplemented plots, 20\%; B2-supplemented plots, $28.30 \%$ ).

Table 3. Cob morphological data based on treatment. Data are expressed as mean \pm standard deviation. Control: plots without biochar; B1: plots supplemented with biochar B1; B2: plots supplemented with biochar B2.

\begin{tabular}{ccccc}
\hline Treatment/Cob & $\begin{array}{c}\text { Cob Insertion } \\
\text { Height }(\mathbf{c m})\end{array}$ & Length $(\mathbf{m m})$ & Perimeter $(\mathbf{m m})$ & Diameter $(\mathbf{m m})$ \\
\hline B1 & $81.88 \pm 8.86^{*}$ & $217.87 \pm 24.66^{* *}$ & $155.18 \pm 29.31 *$ & $48.79 \pm 6.53^{*}$ \\
B2 & $80.55 \pm 8.84$ & $229.89 \pm 75.53^{* *}$ & $144.88 \pm 26.39$ & $44.52 \pm 4.08^{*}$ \\
C1 & $82.81 \pm 13.30$ & $197.21 \pm 27.24^{*}$ & $140.33 \pm 9.93$ & $42.05 \pm 6.01$ \\
C2 & $80.78 \pm 11.13$ & $176.49 \pm 27.24^{*}$ & $140.29 \pm 18.82$ & $43.96 \pm 3.38$ \\
\hline
\end{tabular}

Fisher significance test ${ }^{*}: p<0.01 ;{ }^{* *} p<0.001$.

\subsubsection{Fresh Cob Production Data}

The weight of cobs in B1-supplemented plots was significantly higher than that of cobs in other plots (Fisher LSD; $p<0.01$ ) (Figure 1). However, the weight of cobs was not different between the B2-supplemented, C1, and C2 plots (Fisher LSD; $p>0.05$ ) (Table 4).

$(95 \% \mathrm{Cl})$

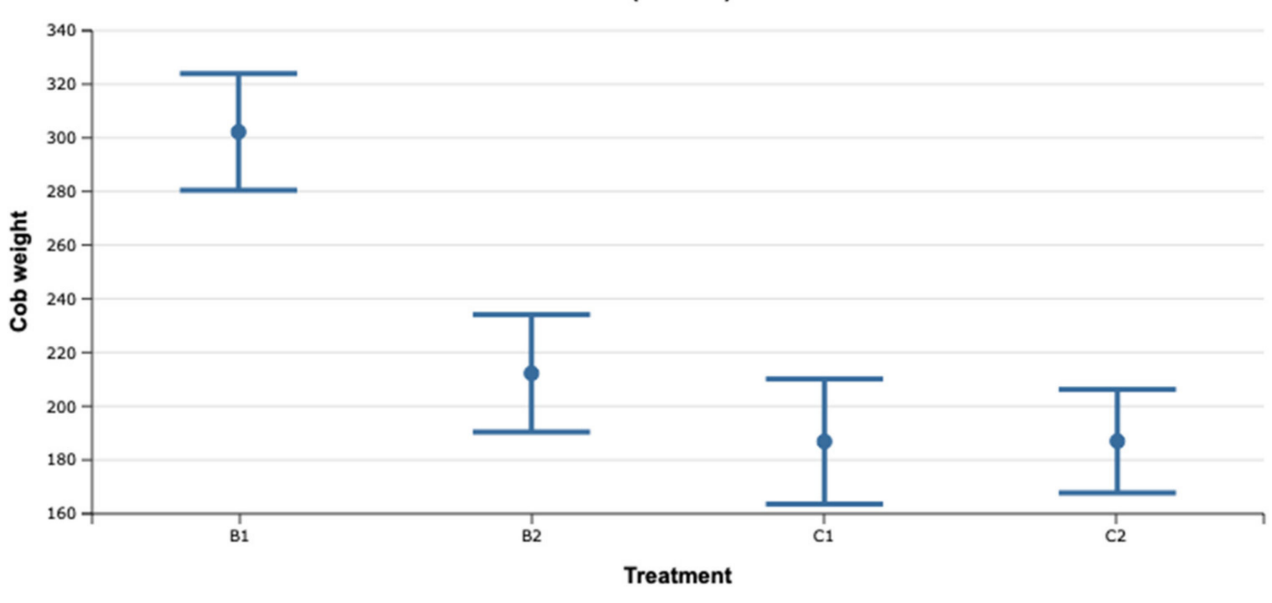

Figure 1. Average fresh cob weight in different treatment groups. Control: plots without biochar; B1: plots supplemented with biochar B1; B2: plots supplemented with biochar B2.

The number of cobs per plant (including plants with two cobs) in B1-supplemented plots was significantly higher than those in the other plots (Fisher LSD; $p<0.01$ ). However, the number of cobs per plant was not different between the B2-supplemented, C1, and C2 plots. Additionally, the number of cobs per plant was significantly different between the $\mathrm{C} 1$ and C2 plots (Fisher LSD; $p<0.05$ ). In B1-supplemented, B2-supplemented, C1, and C2, $17.6 \%, 1.9 \%, 26 \%$, and $0 \%$ of the plants had two cobs, respectively. 
Table 4. Cob production and weight data based on treatment. Data are represented as mean \pm standard deviation. Control: plots without biochar; B1: plots supplemented with biochar B1; B2: plots supplemented with biochar B2.

\begin{tabular}{ccccc}
\hline Treatments & $\begin{array}{c}\text { Fresh Cob Weight } \\
\text { (g/Plant) }\end{array}$ & $\begin{array}{c}\text { Fresh Cob Weight } \\
\text { (g/Cob) }\end{array}$ & $\begin{array}{c}\text { Weight of 100 Grains } \\
\text { (g) }\end{array}$ & $\begin{array}{c}\text { Fresh Weight } \\
\text { Productivity (g/m }{ }^{2} \text { ) }\end{array}$ \\
\hline B1 (68 plants) & $307.28 \pm 138.97^{* *}$ & $302.2 \pm 84.94 * *$ & $43.64 \pm 5.97^{* *}$ & $2028.05 \pm 542.87^{* *}$ \\
B2 (52 plants) & $202.85 \pm 79.20$ & $210 \pm 16$ & $36.43 \pm 4.53$ & $1117.63 \pm 189.7^{*}$ \\
C1 (52 plants) & $231.07 \pm 135.22^{*}$ & $186.5 \pm 84.87$ & $39.46 \pm 4.69$ & $1171.39 \pm 290.32$ \\
C2 (57 plants) & $163.28 \pm 74.77^{*}$ & $187.00 \pm 64.0 *$ & $31.36 \pm 5.40$ & $923.43 \pm 228$ \\
\hline
\end{tabular}

Fisher significance test $*: p<0.01 ; * * 0.001$.

The weights of 100 corn grains in B1-supplemented plots were significantly higher than those in other plots (Fisher LSD; $p<0.01$ ). Meanwhile, the weights of 100 corn grains in C1 plots were significantly higher than those in C2 and B2-supplemented plots (Fisher LSD; $p<0.01$ ). The weights of 100 corn grains were not different between B2-supplemented and C2 plots (Fisher LSD; $p>0.05$ ).

B1-supplemented plots produced significantly more corn than the other plots (Fisher LSD; $p<0.01$ ). However, there was no difference between B2-supplemented, C1, and C2 plots (Fisher LSD $p>0.05$ ). The number of plants in C1, C2, B1-supplemented, and B2-supplemented plots was 52, 57, 68, and 52, respectively.

\subsubsection{Dried Cob Production Data}

The moisture content in the whole fresh cobs was $26.33 \% \pm 4.51$ with no differences between treatment groups (Fisher LSD; $p>0.05$ ). The mean moisture content of the corn grains was $18.82 \pm 4.34$. Additionally, the mean moisture content of corn grains from the B1-supplemented (19.85 \pm 1.18$)$ and B2-supplemented (22.13 \pm 2.62$)$ plots was significantly higher than that of the corn grains from the C1 $(14.77 \pm 1.73)$ and $C 2(12.45 \pm 2.12)$ plots. To estimate the dry grain production, a linear regression curve of the fresh cob weight against the grain weight in each plot was generated, and the grain weight was estimated for all cobs (Table 5). The $R^{2}$ and $p$ values in all cases were $>0.99$ and $<0.01$, respectively. The moisture correction for each treatment was applied to obtain the result of the dry corn grain.

Table 5. Production data, dry weight and yield per square meter. Data are represented as mean \pm standard deviation. Control: plots without biochar; B1: plots supplemented with biochar B1; B2: plots supplemented with biochar B2.

\begin{tabular}{|c|c|c|c|c|}
\hline Treatment & $\begin{array}{l}\text { Equation (Cob Weight } \\
\text { and Grain Weight) }\end{array}$ & $\begin{array}{c}\text { Dried Grain Production } \\
\text { Per Cob }(g)\end{array}$ & $\begin{array}{l}\text { Dried Grain } \\
\text { Production } \\
\text { Per Plant (g) }\end{array}$ & $\begin{array}{c}\text { Dried Grain } \\
\text { Productivity }\left(\mathrm{g} / \mathrm{m}^{2}\right)\end{array}$ \\
\hline B1 & $\begin{array}{c}\text { Grain weight }= \\
-17.05+0.82 * \text { Cob weight } \\
\left(\mathrm{R}^{2}: 0.99\right)\end{array}$ & $152.97 \pm 71.88^{* *}$ & $177.83 \pm 86.52$ ** & $1209.24 \pm 364.57^{* *}$ \\
\hline B2 & $\begin{array}{c}\text { Grain weight }=-3.39+ \\
0.79 * \text { Cob weight }\left(R^{2}: 0.99\right)\end{array}$ & $131.69 \pm 49.32 *$ & $136.76 \pm 56.62$ & $711.14 \pm 116.8$ * \\
\hline $\mathrm{C} 1$ & $\begin{array}{c}\text { Grain weight }= \\
-21.41+0.85^{*} \text { Cob weight } \\
\left(R^{2}: 0.99\right)\end{array}$ & $110.74 \pm 60.11$ & $138.79 \pm 89.98$ & $740.32 \pm 195.20$ \\
\hline $\mathrm{C} 2$ & $\begin{array}{c}\text { Grain weight }= \\
-16.35+0.82 * \text { Cob weight } \\
\left(R^{2}: 0.99\right)\end{array}$ & $100.05 \pm 52.25$ & $100.05 \pm 52.25^{* *}$ & $570.31 \pm 162.54$ \\
\hline
\end{tabular}

Fisher significance test ${ }^{*}: p<0.01{ }^{* *} p<0.001$.

The weight of dry grains per cob in B1-supplemented and B2-supplemented plots was significantly higher than that in $\mathrm{C} 1$ and $\mathrm{C} 2$ plots. Additionally, the dry grain weight per cob was significantly different between B1-supplemented and B2-supplemented plots 
(Fisher LSD; $p<0.01$ ) but not between C1 and C2 plots (Fisher LSD; $p>0.05$ ). The dry grain weight per plant (including the plants with two cobs) in the B1-supplemented plots was significantly higher than that in the other plots (Fisher LSD $<0.01$ ). Additionally, the dry grain weight per plant in the $\mathrm{C} 1$ plot was significantly different from that in the other plots (Fisher LSD; $p<0.01$ ) but was not different between C2 and B2-supplemented plots (Fisher LSD; $p=0.89$ ).

The dry grain weight per square meter was significantly different between B1-supplemented and other plots (Fisher LSD; $p<0.01$ ) but was not different between B2-supplemented, C1, and C2 plots (Fisher LSD; $p>0.05$ ) (Figure 2).

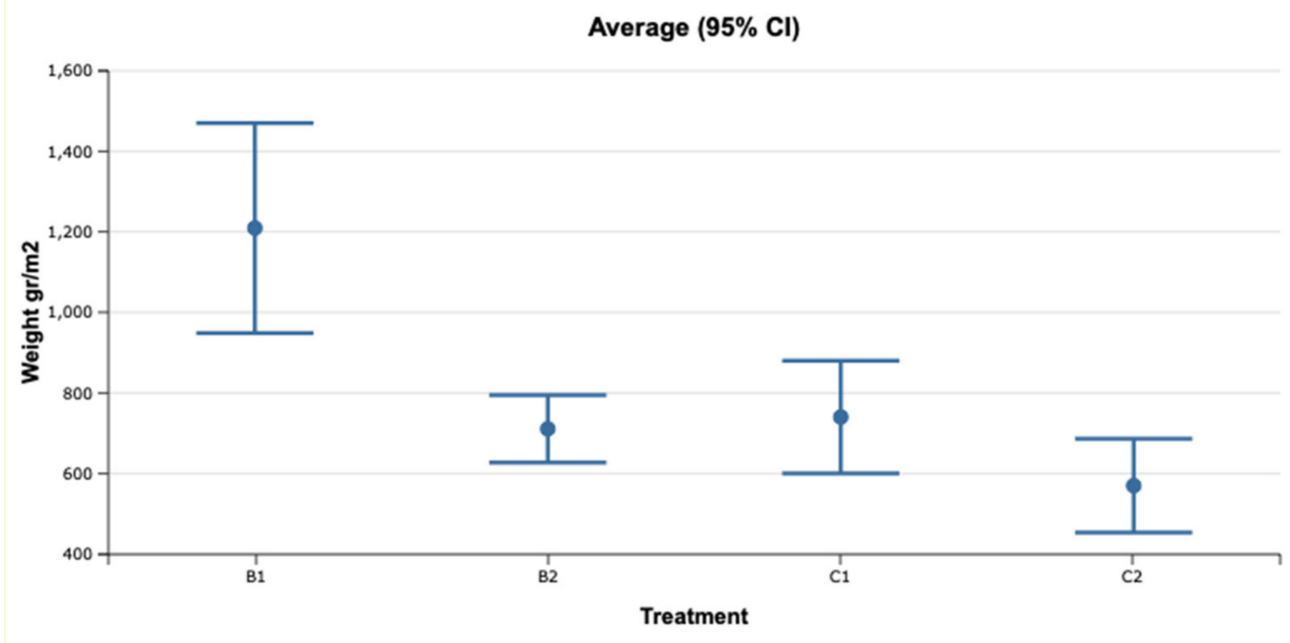

Figure 2. Dry grain weight per square meter in different treatments $(n=10)$. Mean \pm standard deviation. Control: plots without biochar; B1: plots supplemented with biochar B1; B2: plots supplemented with biochar B2.

\section{Discussion}

The effect of biochar on the growth of several plant species has been studied in tropical climates. For example, the beneficial effect of biochar on the growth of rice has been previously reported [26]. Several studies examining the effect of biochar on corn production in Africa, the USA, and Asia have reported that the efficacy of biochar to increase the production of corn ranges from $80-100 \%$ at high concentrations, to no significant results in some cases [32,33]. At low doses, the effect of biochar on plant growth is mitigated. For example, Borchar et al. reported that the supplementation of biochar at doses ranging from $15 \mathrm{~g}$ to $100 \mathrm{~g} / \mathrm{kg}$ did not result in beneficial effects on corn production [34].

In warm climates, the effect of biochar supplementation on plant growth ranged from highly ineffective [35] to highly effective [36]. The effect of biochar on plant species in the Mediterranean climate was examined in control chambers with limited field studies. For example, Baronti et al. reported that corn production increased by $6 \%$ in Italy upon supplementation with biochar at a dose of $10 \mathrm{t} / \mathrm{ha}$ of soil. The production of perennial grasses increased by $120 \%$ upon supplementation with biochar at a dose of $60 \mathrm{t} / \mathrm{ha}$ of soil [24]. However, biochar supplementation did not markedly affect the crop production in temperate areas, such as New York with a rainfall of more than $900 \mathrm{~L}$ although the retention of added $\mathrm{N}$ increased [30]. The production of wheat (Triticum durum L.), sunflower (Helianthus annus), or annual species, such as Lupinus increased in the Mediterranean climate upon supplementation of biochar from olive wood [37-39].

The results of this study demonstrated that in contrast to B2, B1 enhanced cob weight, grain weight, and cob production. The dry grain weight per square meter in B1-supplemented plots increased by $84.58 \%$ when compared with that in $\mathrm{C} 1$ and $\mathrm{C} 2$ plots (63.37\% higher when compared to the best results). The fresh weight in B1-supplemented plots increased by $93.69 \%$ when compared with that in C1 and C2 plots $(73.18 \%$ higher 
when compared to the best plots). This indicated that the application of B1 (but not B2) enhanced corn production.

The variability in biochar definition can account for the lack of homogeneity of the results reported in various studies. For example, Jones et al. reported that biochar did not affect corn growth upon supplementation with amounts similar to those used in this study [40]. However, the authors examined vegetation data but did not analyze harvest data. In a recent review, Ippolito et al. analyzed data from multiple experiments and concluded that temperature and origin of raw material may explain the variability in the effects of biochar [41]. Rajkovich et al. studied the effect of the starting raw materials and the biochar pyrolysis temperature on corn production. The total biomass production was similar upon treatment with $0.2 \%, 0.5 \%$, and $2 \%$ but significantly decreased upon treatment with 7\% biochar. However, the authors reported significant differences in the effects of different types of biochar. The type of raw material had an eight times higher effect on corn biomass production than pyrolysis temperature [21]. Butnan et al. examined the addition of two types of biochar obtained by different processes at different temperatures (350 and $800^{\circ} \mathrm{C}$ ). Biochar obtained at $350^{\circ} \mathrm{C}$ was highly effective in improving soil properties and corn growth [42]. In the same line, Guo 2020 points out three main factors to improve the biochar application effectiveness: right biochar source, right application rate, and right placement in soil [43].

Spokas et al. suggested that products with limited commonalities are considered equivalent [32]. For example, Manyá recommends that it is important to describe the biochar composition and main variables when its effects on production are reported [44]. The results of this study confirm that two types of biochar obtained from pine wood with different compositions exhibited differential effects.

In addition to its chemical and biological properties, the structural properties of biochar contribute to its improved performance in sandy soils or areas with water deficit as its porous structure can increase the water retention capacity $[14,45]$ and consequently enhance the water available to plants [46,47]. In this study, B1 (but not B2) directly and markedly improved corn production.

The soil analysis revealed that the application of biochar did not affect most soil nutrients, such as nitrogen, phosphorus, and potassium. However, biochar affected some soil properties, such as conductivity, sulfate, magnesium, or saturation percentage. Recently, Olmo et al. reported that biochar supplementation decreased the bulk density and compaction of the soil and increased its water retention capacity. This is consistent with the results of this study as corn is cultivated in a Mediterranean climate where water availability is a determining factor for its growth [39]. Other authors have reported that biochar supplementation increases the conductivity of soil $[48,49]$. Furthermore, biochar enhances soil nutrient retention. The findings of this study indicated that B1 supplementation increases the $\mathrm{Mg}$ content. The increased availability of $\mathrm{Ca}$ and $\mathrm{Mg}$ in the soil promotes crop production $[18,50]$.

\section{Profitability of Biochar Application}

Both short-term and medium-term profitability must be ensured for the successful application of biochar by farmers or administrations. Economic profitability is an essential factor for the application of biochar as a carbon sink by farmers. Filiberto and Gaunt developed an economic model in 2013 to determine the economic value of biochar application. They indicated that the cost of fixing one ton of environmental $\mathrm{CO}_{2}$ should be $\$ 87.5$ to justify the costs [51]. Therefore, the agronomic value of biochar should cover the difference between this cost and the real cost of fixing one ton of $\mathrm{CO}_{2}$.

In the Mediterranean region, a ton of corn with $14 \%$ moisture content is approximately $€ 185$ [52]. One hectare of land in the Mediterranean area can generate approximately 12 tons [53]. Therefore, a 63\% improvement in dry grain production (the improvement rate relative to the best improvement observed in the untreated plot) can result in the yield of an additional $7.44 \mathrm{t}$. If the price for one ton of corn is $€ 185$, the input increase in one 
hectare is $€ 1376.4$, considering that the harvest costs are similar regardless of the harvest amount. (Table 6). This amount would be the maximum cost that a farmer could afford in a year without losing profits. The findings of this study indicate that biochar must be incorporated at a dose of $4 \mathrm{~kg} / \mathrm{m}^{2}(40 \mathrm{t} / \mathrm{ha})$.

Table 6. Main variables in the application of biochar in corn.

\begin{tabular}{ccccc}
\hline Biochar/ha & $\begin{array}{c}\text { Cost of a Ton of } \\
\text { Dry Corn }\end{array}$ & $\begin{array}{c}\text { Average } \\
\text { Production }\end{array}$ & Improvement/ha & $\begin{array}{c}\text { Increasing } \\
\text { Input }\end{array}$ \\
\hline $40 \mathrm{t} / \mathrm{ha}$ & $€ 185$ & $12 \mathrm{t} / \mathrm{ha}$ & $7.44 \mathrm{t}$ & $€ 1376.4 / \mathrm{ha}$ \\
\hline
\end{tabular}

Based on the estimated cost of approximately $€ 190$ per ton of biochar, which is the medium price of this product on some websites in Spain, (a), the cost of its application at $4 \mathrm{~kg} / \mathrm{m}^{2}$ would be approximately $€ 7600$. However, other authors have estimated a cost of approximately $€ 6000$ [51]. Therefore, biochar should improve corn production for at least 5.52 years to make its purchase profitable assuming that it can be implemented at a low cost with the machinery of the farmers. Similarly, Dokoohaki et al. indicated that the application of 5-15t of biochar per hectare is efficient in areas of the USA with poor soils for corn production with increased production maintained for 5 to 10 years. However, these applications are not efficient for other studied crops (soybeans and wheat) or high-quality soils [54].

One option to reduce the costs is to include the subsidized price of one ton of $\mathrm{CO}_{2}$ that is no longer emitted in the income of farmers or by reducing the cost of biochar (for economic purposes). According to the data provided by Filiberto and Gaunt in 2013, one ton of biochar reduces the emission of 2.06 tons of $\mathrm{CO}_{2}$ [51]. The price of $\mathrm{CO}_{2}$ in 2021 has increased to $50 €$ per ton, but a price of $€ 30$ per ton is applied because it may be more realistic in the long term. Therefore, the application of biochar provides $€ 2472 /$ ha in emission savings if 40 tons are used, which would reduce the cost for farmers by approximately one-third.

Several studies have reported the reduction of expenses with fertilization and irrigation. However, it is difficult to calculate costs with such data. If biochar could be used to avoid fertilization, the cost can be reduced by $50 \%$ for the unfertilized plots. Considering an estimated cost of approximately $€ 507.95$ per hectare of corn maize [55], the estimated saving is $€ 253.97$. Moreover, the cost of water is estimated to be $38 \%$ of the total cost in the Mediterranean irrigated areas [56], which is approximately $€ 700-800$ per hectare. As water prices are high, savings in water efficiency and fertilization can enable the profitable application of biochar. Considering an annual saving of $25 \%$ of water (€200) and a similar saving for fertilization, this could generate an annual improvement of more than $€ 453.97$ per hectare, which can amortize the investment made by the farmer for the incorporation of biochar at $€ 190 / \mathrm{t}$ in three years (Table 7 ).

Table 7. Potential savings with the use of biochar.

\begin{tabular}{ccccccc}
\hline $\mathrm{CO}_{2}$ Value & $\begin{array}{c}\text { Savings in } \\
\text { Fertilization }\end{array}$ & $\begin{array}{c}\text { Irrigation } \\
\text { Savings }\end{array}$ & $\begin{array}{c}\text { Biochar Cost } \\
€ 190 / \mathbf{t}\end{array}$ & $\begin{array}{c}\text { Crop } \\
\text { Improvement } \\
\text { (Corn Value) }\end{array}$ & $\begin{array}{c}\text { Time to } \\
\text { Amortize } \\
\left.\text { (without } \mathrm{CO}_{2}\right)\end{array}$ & $\begin{array}{c}\text { Time to } \\
\text { Amortize (with } \\
\left.\mathbf{C O}_{2}\right)\end{array}$ \\
\hline$€ 2472 / \mathrm{ha}$ & $€ 253$ & $€ 200$ & $€ 7600$ & $€ 1376.4$ & 4.15 years & 2.80 year \\
\hline
\end{tabular}

The results obtained in this study for corn must be replicated and maintained for at least 4 years for the use of biochar to be profitable. Some studies estimate productivity improvements for 5 to 10 years, while others consider up to 30 years in soil improvement [57]. Thus, while short-term improvements are important for the farmer and it is essential to obtain short-term results in this type of business, more long-term trials should be carried out. Additionally, the incorporation of the value of non-emitted $\mathrm{CO}_{2}$ through $\mathrm{CO}_{2}$ bonds 
or compensation for companies will recover the investment in approximately 3 years in the case of corn, which is reasonable if constant improvements are expected for about 10 years.

These findings indicate that the application of biochar can be profitable in high valueadded crops for which production increases have a high economic value. However, the use of biochar is discouraged in low value-added products, such as wheat and barley.

\section{Materials and Methods}

\subsection{Biochar}

Two types of biochar from pine wood chips with different characteristics were used. Pyrolysis was performed in a semi-industrial continuous feed pyrolysis plant, which produces biochar, wood vinegar, and bio-oil, with a syngas circulation system to feed the biomass heating. This prototype was developed as part of the EU Lignobiolife project, CCM/ES000051.

\subsection{Field Experiments}

The field experiments were performed using the facilities of the Royal Botanic Gardens, University of Alcalá (Madrid, Spain). Four experimental fields were divided into 40 randomly arranged plots each with an area of $1 \mathrm{~m}^{2}$. Biochar B1 and biochar B2 were supplemented in 20 plots (10 plots/supplementation). In C1 and C2 (10 plots/each) plots, no fertilizer or compost was used. B1-supplemented and C1 plots were separated from B2-supplemented and C2 plots by approximately $10 \mathrm{~m}$. Biochar $\left(4 \mathrm{~kg} / \mathrm{m}^{2}\right)$ was added in December 2019 and mixed with the soil using a power tiller.

Each plot had two planting rows with a spacing of $50 \mathrm{~cm}$ between rows and $30 \mathrm{~cm}$ between plants. In total, 272 plants emerged and developed. The plots were protected from rabbits and rodents with a metal mesh. For protection against birds, a semi-rigid plastic mesh was placed in an arch with an enclosure height of $2 \mathrm{~m}$.

A drip irrigation system regulated with a solenoid valve and TBOSS II programmer was installed in all plots.

The corn was harvested in the first week of September when the cobs had already developed and the leaves were starting to turn yellow. The number of plants in C1, C2, B1-supplemented, and B2-supplemented plots was 52, 57, 68, and 52 plants, respectively. The cob for each plant was identified. The height of the insertion point of the cob in the plant and the cob number was recorded. The diameter, perimeter, length, weight, and number of rows in the center were measured for each cob. Additionally, the fully developed cobs covered with grains were recorded. The largest and the smallest cobs were collected from each plot $(n=40)$, and the grains and cobs were weighed separately. Additionally, the weight of 30 grains was recorded. Subsequently, the weight of grain in each cob was estimated using Pearson's linear regression analysis.

Furthermore, 80 cobs were selected (20 cobs per plot) and dried to estimate the difference between fresh weight and dry weight of both whole cobs and grains. A linear regression curve was generated to estimate the corn dry weight for all cobs.

\subsection{Soil Analysis}

In total, eight soil samples were collected before the application of biochar in the plots before planting and eight soil samples were collected after the application and harvest. In total, 16 samples were analyzed. The superficial $25 \mathrm{~cm}$ of soil was selected to analyze the $\mathrm{pH}$, conductivity at $20^{\circ} \mathrm{C}$, sodium adsorption ratio, chloride, nitrate, sulfate, phosphate, carbonate, bicarbonate, saturation moisture content, sodium, potassium, calcium, magnesium, cation ratios and exchange (sodium, potassium, calcium, magnesium, cation exchange capacity (CEC)), total nitrogen, assimilable potassium, assimilable phosphorus, easily assimilable organic matter, $\mathrm{C} / \mathrm{N}$ ratio, and texture (sand, silt, and clay) of each sample. The analyses were performed under controlled laboratory conditions (Tentamus Company, Las Rozas, Madrid, Spain). 


\subsection{Biochar Analysis}

The biochar supplied by Neoliquid was weighed and measured. The digestion, gravimetry, moisture content at $105{ }^{\circ} \mathrm{C}(\mathrm{UW})$, electrical conductivity at $25^{\circ} \mathrm{C}$, organic matter, organic carbon, carbon/nitrogen ratio, total humic extract, humic acid and fulvic acid, in each biochar were analyzed at Eurofins Agroambiental S (Sidamon, Lleida, Spain).

\subsection{Statistical Analysis}

The data were analyzed using analysis of variance, followed by Fisher's test. Linear regression analyses were performed to estimate grain weight per cob. All statistical analyses were performed using Statplus 7.1. (AnalystSoft Inc., Walnut, CA, USA).

\subsection{Economic Analysis}

Biochar prices were obtained by reviewing different websites in Spain and Europe [58-60]. The price per ton of corn and the costs of its cultivation, fertilizers and water were taken from the average values in 2020 in Spain from agricultural organizations $(54,57)$. The cost per ton of $\mathrm{CO}_{2}$ was the average for 2020 and early 2021, averaging $30 € / \mathrm{t}$, although in 2021 it has reached $50 € / \mathrm{t}$.

\section{Conclusions}

The results of this study demonstrated that the application of biochar B1 increased corn production by $63.4-84 \%$ based on the dry grain weight in the first year. However, biochar B2, which was partially pyrolyzed, did not significantly affect corn production. The soil supplemented with B1 exhibited enhanced levels of sulfate, magnesium, and saturation percentage in addition to increased retention of nitrates after planting. It is estimated that it would take approximately 4 years to amortize the investment, with an estimated price of $€ 190$ per ton of biochar and also considering a 50\% reduction of the fertilization costs and a $25 \%$ reduction of the irrigation costs with the maintenance of corn production over the years. If the $\mathrm{CO}_{2}$ emission is reduced by 2.06 tons using one ton of biochar and sold to the emissions market, the amortization could be reduced to approximately 3 years. These data demonstrated a marked improvement in crop production with high-quality biochar and provided a strategy for the utilization of this type of material in high value-added crops. However, the economic profitability will be low in low value-added crops.

Author Contributions: Conceptualization, J.L.A. and M.T.M.; methodology, J.L.A.; software, J.L.A.; validation, J.L.A. and M.T.M.; formal analysis, J.L.A. and M.T.M.; investigation, J.L.A. and M.T.M.; resources, J.L.A., S.G. and M.P.; data curation, J.L.A.; writing-original draft preparation, J.L.A.; writing-review and editing, J.L.A. and M.T.M.; visualization, J.L.A.; supervision, J.L.A., S.G. and M.P.; project administration, J.L.A., S.G. and M.P.; funding acquisition, J.L.A., S.G. and M.P. All authors have read and agreed to the published version of the manuscript.

Funding: This research was supported by the project European funds Lignobiolife, LIFE 17 CCM/ES/ 000051 (www.lignobiolife.com, 20 May 2021). The Lignobiolife project was funded with the support of the LIFE Programme of the European Union. This publication only reflects the views of the authors, and the Commission cannot be held responsible for any use which may be made of the information contained therein.

Institutional Review Board Statement: Not applicable.

Data Availability Statement: Data can be requested from the author J.L.A.

Acknowledgments: The authors thank Neoliquid Advanced Biofuels and Biochemicals S.L. for providing biochar and the Center for Applied Chemistry and Biotechnology of the University of Alcalá (CQAB) for its technical support. We also thank the Royal Botanical Garden of Alcalá de Henares for collaboration.

Conflicts of Interest: The authors declare no conflict of interest. 


\section{References}

1. Czajczyńska, D.; Anguilano, L.; Ghazal, H.; Krzyżyńska, R.; Reynolds, A.J.; Spencer, N.; Jouhara, H. Potential of pyrolysis processes in the waste management sector. Therm. Sci. Eng. Prog. 2017, 3, 171-197. [CrossRef]

2. Bridgwater, A.V.; Peacocke, G.V.C. Fast pyrolysis processes for biomass. Renew. Sustain. Energy Rev. 2000, 4, 1-73. [CrossRef]

3. Aguirre, J.L.; Baena, J.; Martín, M.T.; Nozal, L.; González, S.; Manjón, J.L.; Peinado, M. Composition, Ageing and Herbicidal Properties of Biomass Pyrolysis. Energies 2020, 23, 2418. [CrossRef]

4. Aguirre, J.L.; Baena, J.; Martín, M.T.; González, S.; Manjón, J.L.; Peinado, M. Herbicidal effects of wood vinegar on nitrophilous plant communities. Food Energy Secur. 2020, 9, e253. [CrossRef]

5. Ahadiyat, Y.R.; Hadi, S.N.; Herliana, O. Application of wood vinegar coconut shell and NPK fertilizer to maintain sustainable agriculture of upland rice production. J. Degrad. Min. Lands Manag. 2018, 5, 1245-1250. [CrossRef]

6. Mungkunkamchao, T.; Kesmala, T.; Pimratch, S.; Toomsan, B.; Jothityangkoon, D. Wood vinegar and fermented bioextracts: Natural products to enhance growth and yield of tomato (Solanum lycopersicum L.). Sci. Hortic. 2013, 154, 66-72. [CrossRef]

7. Zhu, K.; Gu, S.; Liu, J.; Luo, T.; Khan, Z.; Zhang, K.; Hu, L. Wood Vinegar as a Complex Growth Regulator Promotes the Growth, Yield, and Quality of Rapeseed. Agronomy 2021, 11, 510. [CrossRef]

8. Luo, X.; Wang, Z.; Meki, K.; Wang, X.; Liu, B.; Zheng, H.; You, X.; Li, F. Effect of co-application of wood vinegar and biochar on seed germination and seedling growth. J. Soils Sediments 2019, 19, 3934-3944. [CrossRef]

9. Ye, X.; Lei, X.; Wang, C.; Li, Q.; Yuan, W.; Li, Z. Study on Selective Pyrolysis of Biomass for Production of Upgraded Bio-Oil. In Proceedings of the E3S Web Conference, Shanghai, China, 16-18 August 2019.

10. Ren, Y.; Zhang, L.; Duan, W.; Han, Z.; Guo, J.; Heydenrych, M.D.; Zhang, A.; Nie, K.; Tan, T.; Liu, L. Performance of bitumen coating sheet using biomass pyrolysis oil. J. Air Waste Manag. Assoc. 2020, 70, 219-227. [CrossRef]

11. Guo, M.; Uchimiya, S.M.; He, Z. Agricultural and Environmental Applications of Biochar: Advances and Barriers; Soil Science Society of America, Inc.: Madison, WI, USA, 2015; pp. 495-504. [CrossRef]

12. Yazhini, G.; Abishek, R.; Ilakiya, T.; Shanmugapriya, S.; Piriya, R.S. Beneficial Effects of Biochar on Agriculture and Environments. Int. Res. J. Pure Appl. Chem. 2020, 74-88. [CrossRef]

13. Hossain, M.K.; Strezov, V.; Yin Chan, K.; Nelson, P.F. Agronomic properties of wastewater sludge biochar and bioavailability of metals in production of cherry tomato (Lycopersicon esculentum). Chemosphere 2010. [CrossRef] [PubMed]

14. Ding, Y.; Liu, Y.; Liu, S.; Li, Z.; Tan, X.; Huang, X.; Zeng, G.; Zhou, L.; Zheng, B. Biochar to improve soil fertility. A review. Agron. Sustain. Dev. 2016, 36, 36. [CrossRef]

15. Hussain, M.; Farooq, M.; Nawaz, A.; Al-Sadi, A.M.; Solaiman, Z.M.; Alghamdi, S.S.; Ammara, U.; Ok, Y.S.; Siddique, K.H.M. Biochar for crop production: Potential benefits and risks. J. Soils Sediments 2017, 17, 685-716. [CrossRef]

16. Baiamonte, G.; De Pasquale, C.; Marsala, V.; Cimò, G.; Alonzo, G.; Crescimanno, G.; Conte, P. Structure alteration of a sandy-clay soil by biochar amendments. J. Soils Sediments 2015, 15, 816-824. [CrossRef]

17. Omondi, M.O.; Xia, X.; Nahayo, A.; Liu, X.; Korai, P.K.; Pan, G. Quantification of biochar effects on soil hydrological properties using meta-analysis of literature data. Geoderma 2016, 274, 28-34. [CrossRef]

18. Laghari, M.; Naidu, R.; Xiao, B.; Hu, Z.; Mirjat, M.S.; Hu, M.; Kandhro, M.N.; Chen, Z.; Guo, D.; Jogi, Q.; et al. Recent developments in biochar as an effective tool for agricultural soil management: A review. J. Sci. Food Agric. 2016, 96, 4840-4849. [CrossRef]

19. Zhang, L.; Rana, I.; Shaffer, R.M.; Taioli, E.; Sheppard, L. Exposure to glyphosate-based herbicides and risk for non-Hodgkin lymphoma: A meta-analysis and supporting evidence. Mutat. Res. Rev. Mutat. Res. 2019, 781, 186-206. [CrossRef] [PubMed]

20. Rogovska, N.; Laird, D.A.; Karlen, D.L. Corn and soil response to biochar application and stover harvest. F. Crop. Res. 2016, 187, 96-106. [CrossRef]

21. Rajkovich, S.; Enders, A.; Hanley, K.; Hyland, C.; Zimmerman, A.R.; Lehmann, J. Corn growth and nitrogen nutrition after additions of biochars with varying properties to a temperate soil. Biol. Fertil. Soils 2012, 48, 271-284. [CrossRef]

22. Prakongkep, N.; Gilkes, R.J.; Wisawapipat, W.; Leksungnoen, P.; Suaysom, W.; Hammecker, C. The response of sweet corn to biochar and chemical fertilizer applications for a sandy soil. J. Agric. Crop Res. 2020, 8, 297-304. [CrossRef]

23. Montagnoli, A.; Baronti, S.; Alberto, D.; Chiatante, D.; Scippa, G.S.; Terzaghi, M. Pioneer and fibrous root seasonal dynamics of Vitis vinifera $\mathrm{L}$. are affected by biochar application to a low fertility soil: A rhizobox approach. Sci. Total Environ. 2021, 751, 141455. [CrossRef] [PubMed]

24. Baronti, S.; Alberti, G.; Vedove, G.D.; di Gennaro, F.; Fellet, G.; Genesio, L.; Miglietta, F.; Peressotti, A.; Vaccari, F.P. The biochar option to improve plant yields: First results from some field and pot experiments in Italy. Ital. J. Agron. 2010. [CrossRef]

25. Xie, Z.; Xu, Y.; Liu, G.; Liu, Q.; Zhu, J.; Tu, C.; Amonette, J.E.; Cadisch, G.; Yong, J.W.H.; Hu, S. Impact of biochar application on nitrogen nutrition of rice, greenhouse-gas emissions and soil organic carbon dynamics in two paddy soils of China. Plant Soil 2013. [CrossRef]

26. Hamzah, Z.; Shuhaimi, S.N.A. Biochar: Effects on crop growth. In Proceedings of the IOP Conference Series Earth and Environmental Science 215, Yogyakarta, Indonesia, 20-24 August 2017.

27. Mukhina, I.; Rizhiya, E.; Bankina, T. Biochar effect on nutrients availability to barley. Environ. Res. Eng. Manag. 2020, 76, 43-53. [CrossRef]

28. Karthik, A.; Duraisamy, V.K.; Prakash, A.H. Influence of different sources of biochar on soil physical and chemical properties in cotton (Gossypium hirsutum L.). J. Pharmacogn. Phytochem. 2019, 8, 2051-2055. 
29. Upadhyay, K.P.; Dhami, N.B.; Sharma, P.N.; Neupane, J.D.; Shrestha, J. Growth and yield responses of potato (Solanum tuberosum L.) to biochar. Agraarteadus 2020, 31, 244-253. [CrossRef]

30. Güereña, D.; Lehmann, J.; Hanley, K.; Enders, A.; Hyland, C.; Riha, S. Nitrogen dynamics following field application of biochar in a temperate North American maize-based production system. Plant Soil 2013, 365, 239-254. [CrossRef]

31. Karer, J.; Wimmer, B.; Zehetner, F.; Kloss, S.; Feichtmair, S.; Kitzler, B. Biochar application to temperate soils-Effects on soil fertility and crop yield. Agric. Food Sci. 2013, 22, 390-403. [CrossRef]

32. Spokas, K.A.; Cantrell, K.B.; Novak, J.M.; Archer, D.W.; Ippolito, J.A.; Collins, H.P.; Boateng, A.A.; Lima, I.M.; Lamb, M.C.; McAloon, A.J.; et al. Biochar: A Synthesis of Its Agronomic Impact beyond Carbon Sequestration. J. Environ. Qual. 2012. [CrossRef]

33. Ch'ng, H.Y.; Ahmed, O.H.; Nik, N.M. Biochar and compost influence the phosphorus availability, nutrients uptake, and growth of maize (Zea mays L.) in tropical acid soil. Pakistan J. Agric. Sci. 2014, 51, 797-806.

34. Borchard, N.; Siemens, J.; Ladd, B.; Möller, A.; Amelung, W. Application of biochars to sandy and silty soil failed to increase maize yield under common agricultural practice. Soil Tillage Res. 2014. [CrossRef]

35. Gaskin, J.W.; Speir, R.A.; Harris, K.; Das, K.C.; Lee, R.D.; Morris, L.A.; Fisher, D.S. Effect of peanut hull and pine chip biochar on soil nutrients, corn nutrient status, and yield. Agron. J. 2010, 102, 623-633. [CrossRef]

36. Baiamonte, G.; Minacapilli, M.; Crescimanno, G. Effects of biochar on irrigation management and water use efficiency for three different crops in a desert sandy soil. Sustainability 2020, 12, 7678. [CrossRef]

37. Alburquerque, J.A.; Salazar, P.; Barrón, V.; Torrent, J.; Del Campillo, M.D.C.; Gallardo, A.; Villar, R. Enhanced wheat yield by biochar addition under different mineral fertilization levels. Agron. Sustain. Dev. 2013. [CrossRef]

38. Alburquerque, J.A.; Calero, J.M.; Barrón, V.; Torrent, J.; del Campillo, M.C.; Gallardo, A.; Villar, R. Effects of biochars produced from different feedstocks on soil properties and sunflower growth. J. Plant Nutr. Soil Sci. 2014. [CrossRef]

39. Olmo, M.; Alburquerque, J.A.; Barrón, V.; del Campillo, M.C.; Gallardo, A.; Fuentes, M.; Villar, R. Wheat growth and yield responses to biochar addition under Mediterranean climate conditions. Biol. Fertil. Soils 2014, 50, 1177-1187. [CrossRef]

40. Jones, D.L.; Rousk, J.; Edwards-Jones, G.; DeLuca, T.H.; Murphy, D.V. Biochar-mediated changes in soil quality and plant growth in a three year field trial. Soil Biol. Biochem. 2012, 45, 113-124. [CrossRef]

41. Ippolito, J.A.; Cui, L.; Kammann, C.; Wrage-Mönnig, N.; Estavillo, J.M.; Fuertes-Mendizabal, T.; Cayuela, M.L.; Sigua, G.; Novak, J.; Spokas, K.; et al. Feedstock choice, pyrolysis temperature and type influence biochar characteristics: A comprehensive meta-data analysis review. Biochar 2020. [CrossRef]

42. Butnan, S.; Deenik, J.L.; Toomsan, B.; Antal, M.J.; Vityakon, P. Biochar characteristics and application rates affecting corn growth and properties of soils contrasting in texture and mineralogy. Geoderma 2015, 237, 105-116. [CrossRef]

43. Guo, M. The 3r principles for applying biochar to improve soil health. Soil Syst. 2020, 4, 9. [CrossRef]

44. Manyà, J.J. Pyrolysis for biochar purposes: A review to establish current knowledge gaps and research needs. Environ. Sci. Technol. 2012, 46, 7939-7954. [CrossRef]

45. Egamberdieva, D.; Zoghi, Z.; Nazarov, K.; Wirth, S.; Bellingrath-Kimura, S.D. Plant growth response of broad bean (Vicia faba L.) to biochar amendment of loamy sand soil under irrigated and drought conditions. Environ. Sustain. 2020, 3, 319-324. [CrossRef]

46. Basso, A.S.; Miguez, F.E.; Laird, D.A.; Horton, R.; Westgate, M. Assessing potential of biochar for increasing water-holding capacity of sandy soils. GCB Bioenergy 2013. [CrossRef]

47. Karhu, K.; Mattila, T.; Bergström, I.; Regina, K. Biochar addition to agricultural soil increased CH4 uptake and water holding capacity-Results from a short-term pilot field study. Agric. Ecosyst. Environ. 2011, 140, 309-313. [CrossRef]

48. Yadav, V.; Khare, P.; Deshmukh, Y.; Shanker, K.; Nigam, N.; Karak, T. Performance of biochar derived from Cymbopogon winterianus waste at two temperatures on soil properties and growth of Bacopa monneri. Commun. Soil Sci. Plant Anal. 2018, 49, 2741-2764. [CrossRef]

49. Prapagdee, S.; Tawinteung, N. Effects of biochar on enhanced nutrient use efficiency of green bean, Vigna radiata L. Environ. Sci. Pollut. Res. 2017, 24, 9460-9467. [CrossRef] [PubMed]

50. Hossain, M.Z.; Bahar, M.M.; Sarkar, B.; Donne, S.W.; Ok, Y.S.; Palansooriya, K.N.; Kirkham, M.B.; Chowdhury, S.; Bolan, N. Biochar and Its Importance on Nutrient Dynamics in Soil and Plant; Springer: Singapore, 2020; Volume 2, ISBN 0123456789.

51. Filiberto, D.M.; Gaunt, J.L. Practicality of biochar additions to enhance soil and crop productivity. Agriculture 2013, 3, 715-725. [CrossRef]

52. La Calle, P. La influencia de la humedad en los costes de la recogida del maíz. Agrotecnica 2006, 3, 74-78.

53. Servicio Agronómico Pioneer de Castilla y Leon ¿Por qué hoy Sigue Siendo Rentable Sembrar Maíz en Castilla y León? Available online: https:/ / www.campocyl.es/category / maiz/por-que-hoy-sigue-siendo-rentable-sembrar-maiz-en-castilla-yleon/ (accessed on 21 May 2021).

54. Dokoohaki, H.; Miguez, F.E.; Laird, D.; Dumortier, J. Where should we apply biochar? Environ. Res. Lett. 2019, 14. [CrossRef]

55. Eiriz, G.; Orodea, L.F.; García, L.; Ramírez, G.; Simarro, J.C. Subdirección General de Análisis, Prospectiva y Coordinación. In Resultados Técnico-Económicos, Estudios de Costes y Rentas de las Explotaciones Agrarias; Ministerio de Agricultura y Pesca, Alimentación y Medio Ambiente: Madrid, Spain, 2017; pp. 1-78.

56. Agroptima Rentabilidad del Maíz: Todas las Claves Para Mejorar Esta Campaña-Blog. Available online: https://www. agroptima.com/es/blog/rentabilidad-del-maiz/ (accessed on 21 May 2021). 
57. Kauffman, N.; Dumortier, J.; Hayes, D.J.; Brown, R.C.; Laird, D.A. Producing energy while sequestering carbon? The relationship between biochar and agricultural productivity. Biomass Bioenergy 2014. [CrossRef]

58. Vermichar. Available online: https://www.vermichar.es/biochar/ (accessed on 21 May 2021).

59. Livingchar. Available online: https://www.livingchar.com/producto/biochar-livingchar-6001/ (accessed on 21 May 2021).

60. Biochar Supreme. Available online: https://www.biocharsupreme.com/products/bob-s-ag-hort (accessed on 21 May 2021). 